\title{
Mellem to verdener \\ - Krigsrepræsentationer hos Walter Flex, Ernst Jünger \\ og Erich Maria Remarque
}

I betragtning af den enorme flodbølge af dagbøger, romaner, fortællinger og andre former for litterære bearbejdninger af skyttegravshelvedet, der skyllede ind over de krigsdeltagende lande i kølvandet på første verdenskrig, er det nærmest forbløffende, hvor lidt der har overlevet og stadig (kan) læses ud over et mindre antal kanoniserede tekster, hvortil i hvert fald hører Ford Madox Fords tetralogi Parade's End (1924-28), Robert Graves erindringer Good-bye to All That og Hemingways selvbiografiske roman Farvel til våbnene (begge fra 1929), Jaroslav Hašeks Den gode soldat Svejks eventyr (192123), Arnold Zweigs Kampen om sergenten Grischa (1927) samt et antal mindre tekster, fortrinsvis lyrik (Georg Trakl, Siegfried Sassoon, Wilfred Owen, Apollinaire og et par stykker til). Med lidt god vilje kan man også regne Louis-Ferdinand Célines Rejse til nattens ende (1932) med til gruppen, selv om det ret beset kun er første del af romanen, der handler om krigen. Og endelig er der så de to måske bedst kendte bøger om Den Store Krig af dem alle, Ernst Jüngers I stålstormen, der udkom første gang i 1920, og Erich Maria Remarques Intet nyt fra Vestfronten, der ligesom Graves og Hemingway er fra 1929, hvor der i det hele taget var hausse i krigslitteraturen. ${ }^{1}$

Så godt som fuldstændig glemt er derimod den første tyske bestseller om krigen, Walter Flex' Der Wanderer zwischen beiden Welten (Vandreren mellem begge verdener), der udkom allerede i oktober 1916, i løbet af krigen solgte over 250.000 eksemplarer (svarende til 39 oplag) og helt frem til anden verdenskrig var den sjette mest solgte bog i Tyskland overhovedet, kun overgået af Thomas Manns Buddenbrooks, børnebogen Biene Maja (stadig kendt af de fleste tyske børn fra diverse tv-adaptioner), et par vittighedshæfter - og så føromtalte bog af Remarque, der er og bliver en af de mest solgte romaner i Tyskland og dertil formentlig den mest udbredte tyske 
roman uden for det tyske sprogområde (jf. Müller 1986, Koch 2005).

Når Walter Flex’ bog, som indtil 1966 med jævne mellemrum blev genudgivet på forlaget C.H. Beck, på blot et par generationer er gået fra at være en del af et stort, velrenommeret forlags klassikerrække til stort set ikke længere at eksistere i den offentlige bevidsthed, er det selvfølgelig ikke ganske uden grund. ${ }^{2}$ Næsten uanset hvilken målestok man anlægger, er det svært at finde på noget pænt at sige om Der Wanderer, som må forekomme enhver nutidig læser helt igennem uacceptabel. Trods sine kun 100 sider er den temmelig kedelig, tungt og omstændeligt skrevet, i en svulstig, patetisk stil med en overdreven brug af lyrismer og så er den frem for alt kontamineret med en tidstypisk, og for et moderne publikum usmagelig, heltedyrkelse og dødekult, indlejret i en sakral fejring af tyskheden og den tyske nation. Selvfølgelig kan man også finde reminiscenser af både heltedyrkelse og fædrelandskærlighed hos såvel Jünger som Remarque, men når de i modsætning til Flex stadig bliver læst og genudgivet, er forklaringen utvivlsomt også, at de på intet tidspunkt kommer i nærheden af den salvelsesfulde lovprisning af heltedøden og det hellige offer på nationens alter, som kendetegner Der Wanderer.

Noget af forskellen mellem Flex og hans efterfølgere kan naturligvis forklares med temperament, talent, personlig stil, indre overbevisning og andre mere eller mindre individuelle faktorer, men det er næppe hele forklaringen. Af mindst lige så stor betydning er formentlig aldersforskellen på de tre forfattere og den afstand $i$ tid, der ligger mellem deres tekster - selv om den i Jüngers tilfælde kan synes ubetydelig, så meget mere som I stålstormen er tæt forbundet med de dagbøger, Jünger samvittighedsfuldt førte igennem hele krigen. ${ }^{3}$ En bog som Der Wanderer kunne skrives i krigens første år, til nød også i det andet, men derefter næppe mere, i hvert fald ikke uden at sætte forfatterens troværdighed over styr - dertil var dens beskrivelser af krigen slet og ret for urealistiske og for langt fra stillingskrigens og materielslagenes brutale virkelighed. Men hvis det er korrekt, hvordan forklarer man så, at Der Wanderer fortsatte sin himmelflugt efter krigen, mens I stålstormen omvendt først rigtig begyndte at sælge i 1929, formentlig både som en følge af Remarques popularitet og den berømmelse, Jünger i mellemtiden selv havde 
opnået som politisk skribent, i det mindste i nationalistiske og højreradikale kredse? ${ }^{4}$

Jeg vil i det følgende forsøge at besvare dette spørgsmål ved at se nærmere på et par af de komponenter, der indgår i Flex’ bog, idet jeg antager, at det samtidig kan være med til at kaste lys over de omtalte værker af Jünger og Remarque. En egentlig æstetisk analyse af de tre tekster må man derfor ikke forvente. Teksterne vil først og fremmest blive brugt som kilder til belysning af nogle signifikante politisk-ideologiske aspekter af den tyske krigsrepræsentation under og i det første tiår efter krigen.

\section{I}

Det er som antydet ikke umiddelbart indlysende, at de få år, der skiller Der Wanderer fra I stailstormen skulle have nogen stor betydning for deres respektive fremstillinger af krigen, og der er da heller ikke meget, der tyder på, at de to forfattere har oplevet krigsudbruddet markant forskelligt. Flex, der var født i 1887 og efter sin promotion i 1910 bl.a. havde ernæret sig som huslærer for selveste Bismarckfamilien, var ganske vist nogle år ældre end Jünger, som kun lige akkurat havde nået skelsår, da krigen brød ud. Men begge stammede fra det nationalt sindede dannelsesborgerskab, der udgjorde kernetropperne i den begejstring, der bølgede gennem landet i ugerne efter mobiliseringsbekendtgørelsen den 1. august 1914, og begge var at finde blandt de hundredtusinder af unge og yngre mænd, som løb storm mod hærens rekrutteringskontorer for at melde sig under fanerne ved krigsudbruddet. Til forskel fra Remarque, der er nogle år yngre end Jünger og først blev indkaldt i 1916, er de kort sagt begge draget i krig med 'augustoplevelsen', dvs. oplevelsen af nationens genfødsel i august 1914, i ryggen og en helt urealistisk forestilling om, hvad der ventede dem, med Jüngers ord fra begyndelsen af I stålstormen:

Vi havde forladt auditorier, skole- og arbejdsbænke og var i løbet af få ugers træning smeltet sammen til én stor, begejstret organisme. Opvokset i sikkerhedens tidsalder følte vi alle længslen efter det usædvanlige, efter den store fare. Krigen havde grebet os som en rus. Vi var draget af sted $i$ en regn af blomster, i en beruset stemning 
af roser og blod. Det store, stærke, højtidelige, det måtte krigen jo give os. Vi så den som en mandig dåd, en munter ildkamp på blomstrende, blodbestænkede enge. 'Ingen skønnere død på denne jord ..." Ah, bare man ikke skulle blive hjemme, bare man kunne være med! (Jünger 2012: 9)

Eventyrlyst, længsel efter det ukendte og farlige, den berusende følelse af samhørighed og af at deltage i noget stort og betydningsfuldt, wilhelmismens ideal om heltedøden for fædrelandet og endelig, som ækvivalent hertil, en arkaisk forestilling om krigen som heroismens skueplads og arena - alt dette var, sammen med en mere eller mindre stærk nationalfølelse, de vigtigste ingredienser $\mathrm{i}$ den cocktail, som Flex og Jünger delte med en meget stor del af deres jævnaldrende i august 1914. Men hvor Jünger hurtigt fik et andet og noget mere nøgternt syn på krigen, fortsatte Flex ad samme ideologiske spor, som også ligger til grund for Der Wanderer.

Der Wanderer er den selvbiografiske skildring af et venskab mellem forfatteren og den 20-årige teologistuderende og krigsfrivillige Ernst Wurche, hvis minde bogen også er tilegnet. Bogen begynder med deres møde i foråret 1915, hvor de begge sendes til Posen for at gennemgå en officersuddannelse, og slutter samme efterår, nogle uger eller måneder efter Wurches død, den 23. august 1915. Lidt atypisk for genren er den egentlige hovedperson således ikke jeg-fortælleren, men den stærkt beundrede og idealiserede ven, der repræsenterer de højeste dyder i det flexske univers. Hvori disse består, mejsles fast allerede på de første sider, da jeg-fortælleren og Wurche bryder op fra deres stilling på de lothringske højdedrag omkring Hâtonchatel, hvis jord var "gennemvædet af strømme af helteblod" (Flex 1917: 5), og begiver sig ned ad bjerget til det tog, der skal bringe dem til den anden ende af riget:

Dette menneskes gang kunne være leg eller kamp eller gudstjeneste, alt efter tidspunktet. Det var andagt og glæde. Sådan som dette slanke, smukke menneske i den slidte grå frakke drog ned ad bjerget som en pilgrim, med de klare strålende øjne fulde af målbevidst længsel, var han som Zarathustra, der kommer fra bjergene, eller Goethes vandringsmand. [...]

Hans gang var vilje og glæde. Han gik fra fortid til fremtid, fra læreårene gik han over til sine år som mester. Bag ham forsvandt højdedragene, hvor han havde udført skansearbejde med hakke og spade [...], 
skyttegravene, hvor han på alle tidspunkter af dagen og natten havde gjort vagttjeneste, og jordhullerne og dækningsgravene, hvor han igennem så mange måneder havde haft et godt kammeratskab med håndværkere, fabriksarbejdere og polske landarbejdere. Han havde igennem seks måneder båret den grå frakke uden bånd og knap, og han var ikke blevet sparet for nogen af de hårdeste eller laveste tjenester. Nu gik han ned ad bjerget for at blive fører. (Flex 1917: 6f)

At Wurche besidder alle de egenskaber, der skal til for at sikre Tyskland sejren, kan ingen således være i tvivl om. Han er på én gang ydmyg og selvbevidst, gudfrygtig og stolt, en nærmest overjordisk yndling, der kun tåler sammenligning med digterguden Goethe og Nietzsches forkynder af overmennesket, som naturligvis begge er at finde $\mathrm{i}$ hans tornyster, side om side med Det Nye Testamente. Hvad der umiddelbart tager sig ud som den rene gudbespottelse, viser sig dog netop at være et højere udtryk for selvsamme klasseog standsovergribende folkefællesskab, som fortælleren netop har besværget i kammeratskabet mellem de forskellige samfundsgrupper: "Det er ikke anderledes med bøger end med mennesker. De kan være så forskellige, som de vil - blot skal de være stærke og ærlige og kunne hævde sig, det giver det bedste kammeratskab." (Flex 1917: 9). Styrke, mod, udholdenhed og disciplin gør det ikke alene, forstår man. Den mønstergyldige frontofficer er både krop og ånd, en vandrer mellem to verdener, der ikke alene skal føre sine folk i slaget, men også være dem en åndelig fører.

Hvor dette personlighedsideal stammer fra, er allerede antydet med henvisningen til Nietzsches Zarathustra og Goethe, som for det tyske borgerskab var den ypperste repræsentant for geni- og dannelsestanken. Men dertil kommer en særdeles vigtig tilføjelse: Wurche er passioneret Wandervogel og tilhører som sådan den borgerlige ungdomsbevægelse, ${ }^{5}$ der opstod i 1890 erne som en reaktion mod wilhelmismens kunstige repræsentationskultur og den urbane livsform i almindelighed. Som navnet antyder, var ungdomsbevægelsen i høj grad et generationsoprør, rettet mod forældregenerationens optagethed af materielle værdier. Mod dette opponerede de unge ved at vende byen ryggen, søge ud i naturen - og vandre. Såvel Wandervogel, der blev dannet i 1901, som de mange efterfølgende grupper og organisationer af tilsvarende art var i princippet upolitiske - det fælles for ungdomsbevægelsen var naturoplevelserne, livet 
under åben himmel og kammeratskabet. Men den bagvedliggende utopi om "at forme sit liv efter egen bestemmelse, på eget ansvar, med indre sandfærdighed" - som det hedder i det valgsprog, der blev vedtaget på den første tyske ungdomsdag i oktober 1913 var politisk let antændelig, ikke mindst i sine mere kollektivistiske former.

Der Wanderer er over lange stræk en gennemspilning af denne særegne blanding af kulturkritik, fællesskabskult og krops- og naturdyrkelse, og man tager nok ikke fejl $i$ at antage, at bogens titel også er en hilsen til vandrefuglen og hans verden, som får sit modstykke i krigen, da Wurche og Flex sendes til de store mennesketomme rum på østfronten. Her, i de uberørte landskaber i Baltikum, med tyste skove og vilde engdrag, så langt øjet rækker, bliver krigen bogstavelig talt en naturlig fortsættelse af de foregående års ungdomsliv - intet under altså, at Wurche ifølge fortælleren er lige så lidenskabeligt optaget af "folkeslagenes kamp" som af "den tyske ungdoms kamp for sin gode ret til naturlig vækst" (Flex 1917: 42). Der bades, synges, reciteres digte, leges, rides og vandres i den skønne natur, og selv den "taktfaste hamren af et maskingevær" lader sig uden problemer integrere i billedet: '"spætter!' lo Wurche og lod sol og vand slå sammen over sig." (Flex 1917: 22). Særlig påfaldende er ikke mindst de mange beskrivelser af bade- og nøgenscener, der dels er med til at understrege det arkadiske i denne "gudshave" (Flex 1917: 50), dels giver fortælleren lejlighed til at dvæle ved yndlingens smukke krop i en række tableauer, der emmer af århundredskiftets livsreformtanker og naturlighedsidealer. Det kommer vel nok klarest til udtryk i en badescene, der i et veritabelt overkill af citater lader den Goethe-reciterende Wurche fremstå som den skønneste af alle dødelige, Ganymedes, om end i en særlig tidstypisk udgave, nemlig som den soldyrkende yndling fra Fidus' ikonografiske billede Lichtgebet: ${ }^{6}$ Wurche, får vi at vide, lagde hovedet tilbage, lod "majsolen strømme ned over sig [...] og stod så der med frit udbredte arme og åbnede hænder." (Flex 1917: 23f). Og for at ingen skal være i tvivl om, hvem der her sigtes til, lader Flex en tilstedeværende udbryde: "Så mangler vi kun en maler!" (Flex 1917: 24).

Således indrammet kan krigen naturligvis ikke undgå at tage sig overmåde skøn ud, ja, ret beset er det kampen på liv og død, der 
fuldender billedet, giver det den fornødne patos, alvor og dybde. Og selvfølgelig må Wurches største, inderligste ønske være at få lov til at deltage $i$ et stormangreb, om det så bliver hans sidste: "Det må alligevel være skønt!" (Flex 1917: 52). Da fortælleren efter Wurches død opsøger den sørgende mor, kan hun derfor heller ikke andet end glæde sig i smerten over, at sønnen trods alt nåede at få sit store ønske opfyldt. Han døde den heltedød, han havde ønsket sig, og han begraves efter alle krigskunstens regler af fortælleren, sekunderet af et par hengivne oppassere og menige - stedt til "heltehvile" med hjelm og våben ved sin side, en solsikke "som en skinnende lanse" (Flex 1917: 86) i hånden og en anden solsikke placeret på graven, side om side med korset, som et vidnesbyrd om de to verdener, han bevægede sig imellem, livets og dødens, den nyhedenske sol- og naturkult og den lutheranske protestantisme. At disse to magter ikke alene betinger hinanden, men at døden $\mathrm{i}$ virkeligheden hypostaserer ungdommen ved at gøre den evig, er bogens tvivlsomme morale. I modsætning til den foragtelige strådød kan heltedøden, døden på slagmarken, nemlig kun være "den største oplevelse" og en fuldbyrdelse af livet i metafysisk forstand: "Har vi ikke altid været vandrere mellem begge verdener? [...] Du må være hjemme her som der, eller du er det ingen steder." (Flex 1917: 102)

Der Wanderer har som sagt kun ringe litterær eller i normal forstand dokumentarisk værdi. Derimod er den et uhyggeligt klart vidnesbyrd om det konglomerat af ideologi og verdensanskuelse, som en hel generation af tyskere drog i krig for og med, og som kulminerede få måneder inde i krigen i den kendteste af alle tyske hærberetninger, dateret den 11. november 1914: "Vest for Langemarck brød unge regimenter under afsyngelse af 'Deutschland, Deutschland über alles' igennem den fjendtlige stillings første linje og tog den..." (Krumeich 2001: 292) Beretningen var ganske vist det pure opspind, men den gjorde sin virkning. 'Langemarck' blev på én gang symbolet på den heroiske krig, det heltemodige offer for fædrelandet, og en genbekræftelse af 'augustoplevelsen', den berusede samling af nationen ved krigsudbruddet få måneder tidligere. At stillingskrigen på dette tidspunkt allerede var en kendsgerning, og at de unge, utilstrækkeligt uddannede og udrustede tyske regimenter af samme grund blev mejet ned række for række fra de fjendtlige skyttegrave, peger dog samtidig på, at 'Langemarck' også marke- 
rede den symbolske overgang til en ny og meget lidt heroisk krig, kendetegnet ved tomme slagmarker og usynlige fjender (Krumeich 2001: 294f).

Det er mere end noget andet denne Langemarck-myte, der ligger til grund for krigsrepræsentationen i Der Wanderer, endda forlænget til langt ind i det andet krigsår (Medicus 1999: 102). Ideologisk uforbederlig og med en imponerende veludviklet evne til at abstrahere fra skyttegravskrigens realitet fastholder Flex, at førkrigstidens ungdomsbevægelse finder sin højere bestemmelse i krigen, at frontsoldaten forløser vandrefuglen, på samme måde som krigen forløser nationen, og at der går en lige linje fra Luther over pietismen, Goethe og tysk romantik til Nietzsche og Den Store Krig. Og garant for denne kontinuitet er netop vandreren, tekstens centrale metafor. Utopien om at skabe et nyt menneske, som ungdomsbevægelsen også var udtryk for, mærker man derimod ikke meget til hos Flex. I Der Wanderer er det nye menneske så at sige af ældre dato (jf. Sautermeister 1985: 465). Som han vandrer der, i skikkelse af den fromme og renfærdige, poetisk inspirerede og naturforgabte Wandervogel Ernst Wurche, tager han sig snarere ud som et produkt af tysk romantik, den vagabonderende ungersvend i Eichendorffs $A$ us dem Leben eines Taugenichts (1826).

\section{II}

Ernst Jünger var som sagt ikke ubekendt med sådanne forestillinger. Også han drog i krig med hele dette arsenal af mere eller mindre utidssvarende, arkaiske kriger- og helteforestillinger, og det er som nævnt heller ikke vanskeligt at finde reminiscenser heraf $i$ hans fremstilling af krigen, heller ikke i de seneste gennemskrivninger af I stälstormen. ${ }^{7}$ Men hvor Flex omhyggeligt har bortretoucheret alt, der ikke lader sig integrere i den ideologiske grundfortælling $\mathrm{i}$ Der Wanderer, bevares spændingen mellem den klassiske heroismes repertoire og den moderne teknologiske krigsførelse igennem hele bogen, med glorificeringen af frontofficeren over for 'den ukendte soldat', mennesket som rent og skært råmateriale, der ofres $\mathrm{i}$ tusinder og atter tusinder, forskelsløst og anonymt. Selv om Jünger utvivlsomt også ideologiserer sine krigsoplevelser og -erfaringer, er det åbenlyst vigtigt for ham ikke at sætte den dokumentariske værdi 
over styr. Det lader sig måske lettest anskueliggøre ved at kaste et blik på de første udgaver af I stålstormen, der adskiller sig fra de senere ved deres iøjnefaldende paratekstuelle udstyr. Mens de senere udgaver fremstår mere og mere 'rene' og dermed også genremæssigt ubestemmelige, signalerer de første udgaver utvetydigt, hvordan denne bog vil læses: undertitlen Aus dem Tagebuch eines Stoßtruppfübrers (Af en stødtropførers dagbog), fotografiet på frontispicen af forfatteren i fuld mundering, den dobbelte tilegnelse til såvel krigsjournalisten Hermann Hegemann som "mindet om mine faldne kammerater", den lange biografiske notits under forfatternavnet på titelbladet, der oplyser om grad, regiment etc. samt oplysningen om, at bogen er forsynet med " 5 illustrationer og et fotografi af forfatteren" - alt sammen er med til at understrege, at denne bog ønsker at fremstå som en autentisk øjenvidneberetning, og alt sammen forsvinder lidt efter lidt ud af bogen. Endelig indledes de tre første udgaver med et mere eller mindre identisk forord, hvori man allerede fra 1920 kan læse om bogens formål, som er

[...] at skildre sagligt for læseren, hvad en infanterist oplever som skytte og fører i et berømt regiment under den store krig, og hvilke tanker han har gjort sig herom. Den er skrevet på baggrund af mine dagbøger. [...] Mennesket er tilbøjelig til at idealisere sine præstationer, at fortie det hæslige, smålige og dagligdags. Umærkeligt stempler han sig som "helt".

Jeg er ikke krigskorrespondent, jeg fremlægger ingen heltekollektion. Jeg vil ikke beskrive, hvordan det kunne have været, men hvordan det var.

[...] Graden af saglighed, der kendetegner en sådan bog, er målestokken for dens indre værdi. (Jünger 2013: 20)

Interessant nok ledsages denne senere udviskning af autenticitetssignalerende paratekstuelle elementer imidlertid ikke, som man måske ellers kunne forvente, af en tilsvarende tendens på tekstens indholdsside. Tværtimod synes elimineringen af parateksten at gå hånd $\mathrm{i}$ hånd med en stadig større betoning og vægtning af krigens moderne teknologiske aspekter, mens den romantisk-metafysiske krigsfilosofi skrives mere og mere ud af bogen. Hvor Jünger i de tidlige udgaver stadig kan insistere på den enkelte frontsoldats betydning, der i slutningen af kapitlet "Dobbeltslaget ved Cambrai" 
endda hævdes at være "mere afgørende i dag end nogensinde" (Jünger 2013: 483), er tonen langt mere nøgtern i de senere udgaver (jf. Jünger 2012: 205f). Selv om den klassiske heltetopos altså ikke fuldkommen forsvinder, nedtones den fra udgave til udgave, hvilket sætter sit tydelige præg på fremstillingen af krigen. Det bliver allerede klart umiddelbart efter den ovenfor citerede beskrivelse af de højstemte, berusede forventninger til krigen, der kun lige akkurat formuleres på bogens første side, inden de knuses i mødet med Champagnes kridtgrave på næste side. Den faktiske krigsskueplads er, viser det sig, helt anderledes end den imaginerede: Fjenden er usynlig, ingen synes at have blot det mindste overblik over situationen, som på den nytilkomne fremstår aldeles "gådefuld" og "upersonlig" (Jünger 2012: 10), og vigtigst af alt, krigen kræver en øjeblikkelig omstilling af hele sanseapparatet. Det er ikke synet, der er den afgørende sans i moderne krigsførelse, hvor fjenden alligevel ikke kan ses. Det er lugte- og frem for alt høresansen, det kommer an på, soldatens evne til at skelne ufarlige lyde fra farlige, på et splitsekund at afgøre, om en granat har retning mod ham, hvor den vil lande, med hvilken kraft etc.

Mens krigens rum hos Flex er en overvejende visuel repræsentation, der tegnes af vandrerens bevægelse gennem landskabet, er det derfor i langt højere grad akustisk bestemt hos Jünger - som ét stort ekkorum af flaksende, hvislende, hvinende, drønende, pibende, fløjtende, buldrende og gurglende lyde. Vigtigere i denne sammenhæng er dog, om og i givet fald hvordan denne repræsentation korrelerer med de politisk-ideologiske elementer, som åbenlyst findes hos Jünger. Til en start kan det i hvert fald konstateres, at den bratte opvågnen til krigens akustiske rum på de første sider af I stålstormen, efterfølges af en lige så brat forvandling: "[...] samtidig skete der en forandring dybt i mig" (Jünger 2012: 11). Hvori denne forvandling nærmere består, uddybes ganske vist ikke, men det forekommer oplagt at se den som en form for anticipation af den nye mennesketype, der hævdes at være resultatet af de store materielslags "stålbad", og som første gang omtales, da Jüngers deling i slutningen af august 1916 indsættes i "Somme-slagets sagnomspundne brændpunkt, landsbyen Guillemont":

En ordonnans fra et württembergsk regiment meldte sig hos mig 
for at føre min deling ind i den berømte lille by Combles, hvor vi foreløbig skulle forblive som reserve. Det var første gang, jeg så en tysk soldat med stålhjelm, og han forekom mig straks at være fra en fremmed og hårdere verden. Mens jeg sad ved siden af ham i grøften, spurgte jeg nysgerrigt til forholdene i stillingen og hørte en monoton beretning om at sidde $i$ et granatkrater i dagevis uden kontakt og forbindelsesgrave, om uophørlige angreb, om marker af lig, om vanvittig tørst, om vansmægtende sårede og meget mere. Det ubevægelige ansigt, indrammet af stålhjelmens kant, og den monotone stemme, som akkompagneredes af frontens larm, gjorde et spøgelsesagtigt indtryk på os. Nogle få dage havde sat deres præg på denne budbringer, der skulle lede os ind i flammernes rige, og syntes på ubeskrivelig vis at adskille ham fra os andre. (Jünger 2012: 88f)

Set gennem de flexske briller bliver det senest på dette tidspunkt i fremstillingen klart, at der er noget ganske andet på spil i I stålstormen end i Der Wanderer, og at Ernst Wurches senromantiske vandring bogstaveligt talt ender her, på tærsklen til dette flammernes rige, som hos Jünger præsenteres som den egentlige grænse. Har man først krydset den, forstår man, er de klassiske krigerdyder, som Wurche inkarnerer, intet værd, her tæller helt andre ting, som vandrefuglens 'hele menneske' tværtimod synes at stå i vejen for. Først i flammernes rige udsmeltes de egenskaber, som det nye menneske har brug for, hårdhed, kølig objektivitet, elimineringen af enhver form for subjektivitet, en funktionel-maskinel arbejdsetos og endelig en ekstrem grad af specialisering: "Med sådanne mænd kan man kæmpe." (Jünger 2012: 89)

Ingen, der læser passager som disse, kan være i tvivl om, at den tilstræbte nøgternhed i Jüngers fremstilling dækker over en mindst lige så ideologisk farvet krigsfilosofi som Flex', om end af et ganske andet indhold. Mens Langemarck-myten - med alt, hvad dertil hører af ungdommeligt overmod, begejstring og patos, sang, gudfrygtighed og inderlig, næsten religiøs dyrkelse af naturen - insisterer på kontinuitet og overensstemmelse med den nationale dannelsestradition, peger Jüngers frontsoldat omvendt frem mod en ny, fremmed og hårdere tidsalder. Frontsoldaten er bebuderen af det nye menneske, der fødes i skyttegraven, og som radikalt overskærer båndet til traditionen. At Jüngers deling i juli-august 1917 sættes ind netop ved Langemarck og under skansearbejdet støder deres spader "mod geværer, gehæng og patronhylstre tilbage fra 1914" (Jün- 
ger 2012: 163), er derfor ikke uden en vis symbolik. I Jüngers krigsfilosofi repræsenterer Langemarck et ældre sediment, en for længst forgangen tidsalder, på samme måde som pikkelhuen og soldaten, der begejstret kæmper for sit fædreland. Den nye tidsalder begynder i de store materielslag i Verdun og Somme, og den bebudes lidenskabsløst og monotont af ildlutrede krigere med stålhjelm. ${ }^{8}$

\section{III}

For den nutidige læser af Flex og Jünger er der vel ingen tvivl om, at sidstnævnte - al ideologi til trods - kommer en hel del tættere på vores forståelse af første verdenskrig og dens betydning for eftertiden. Mere end nogen anden enkelt begivenhed markerer Den Store Krig for de fleste en symbolsk tærskel mellem førmoderne og moderne tid, mellem en "verden af i går" (Stefan Zweig), der hurtigt fortonede sig i et skær af nostalgi, som den uskyldsrene borgerlige epoke, hvorfra traditionens bånd kunne følges langt tilbage i tiden, og modernitetens rå, brutale og inhumane tidsalder uden nogen fælles normer og værdier. Så meget rigtigt der måtte være i denne opfattelse, kommer den dog i nogen grad til at skygge for den betydning, som Langemarck-myten havde for de efterfølgende begivenheder. Når Flex i langt højere grad end Jünger formåede at fastholde læserne op gennem 1920erne, havde det selvfølgelig nok så meget at gøre med det naturlige behov for at se en mening $\mathrm{i}$ krigen og den enkeltes offer for nationen, og dertil var Der Wanderer alt andet lige væsentlig bedre egnet end Jüngers kuldslåede materielslagsfilosofi. Kaster man et blik på den afgørende rolle, verdenskrigen spillede i opbygningen af den nazistiske mytologi, er det imidlertid klart, at begge komponenter var af uvurderlig betydning. Med Langemarck-myten, 'augustoplevelsen' og det flexske univers delte nazisterne ungdomskulten, idéen om folkefællesskabet, "Blut und Boden"-romantikken og frem for alt den sakrale offer- og dødekult. Men uden myten om det nye menneske, der blev skabt $\mathrm{i}$ Verdun og ved Somme, ville nazismen have manglet den måske vigtigste ideologiske ingrediens. Det er således ikke tilfældigt, at Hitler, der gjorde sig til af at have været med i det sagnomspundne Langemarck-slag, på den ene side benyttede enhver lejlighed til at besværge ånden fra Langemarck, men på den anden side aldrig 
lagde skjul på, at den tyske soldat var gjort af et helt andet stof end de "unge regimenter", der i naiv begejstring skulle have stormet de franske linjer i november 1914 under afsyngelse af "Deutschland, Deutschland über alles". Den tyske soldat var hård, brutal, lidenskabsløs, aggressiv, mere maskine end menneske, den moderne industrielle krigsførelses ækvivalent til arbejderen - en karakteristik, der snarere flugtede med det ikoniske billede af "den grå stålhjelms jernfront" end den troskyldige, uprøvede og utilstrækkeligt udrustede ungdom (Hüppauf 1993: 60ff).

Hvor intimt forbundet begge repræsentationer blev ved med at være i nazismen lader sig i øvrigt meget klart illustrere med et eksempel fra den gigantomaniske nyordning af Berlin, der påbegyndtes i de sidste år op til anden verdenskrig, og hvis planlagte nordsyd-akse netop må forstås som en bombastisk manifestation af de to krigsfilosofier, som Flex og Jünger repræsenterer. Skærende tværs gennem Tiergarten skulle denne 120 meter brede paradevej forbinde Tempelhof i syd med Spreebogen i nord, markeret ved en triumfbue til minde om de faldne i forste verdenskrig - tegnet af Hitler himself! - i den sydlige ende og Albert Speers "Große Halle" i den nordlige, omtrent hvor Kanzleramt ligger i dag, med en kuppel 17 gange så stor som Peterskirkens og plads til ikke færre end 200.000 mennesker. Korrespondancen mellem nord og syd og de to krigsrepræsentationer bliver dog først for alvor til at forstå, når det tilføjes, at triumfbuen på Hitlers forlangende skulle bære samtlige navne på de faldne tyske soldater i verdenskrigen. Meget tydeligere kan det formentlig ikke udtrykkes, hvad der på én gang forbinder og adskiller Langemarck og Verdun, fortid og fremtid: i den ene ende offer- og dødekulten, mindesmærket for verdenskrigens faldne, $i$ den anden ende det, der skulle give dette offer mening og fylde, det fremtidige kultsted for Tysklands nye krigere.

Hvad denne arkitektoniske kimære derimod ikke fortæller så meget om, er indholdet af det, der ligger imellem de to punkter - hvilket vel i større eller mindre grad er kendetegnende for alle mytologiske og ideologiske repræsentationer, som nødvendigvis må tendere mod at reducere nutiden til et uinteressant gennemgangsled, om det så sker med henvisning til en påstået glorværdig fortid eller en forjættende fremtid, en - med Reinhart Kosellecks ord - "ex-post teleologi" (Koselleck 1988: 52), der kan være med til 
at kaste et forklarelsens skær over fortidens ofre. Og alle forskelle ufortalt er der, som vi har set, noget tilsvarende på spil hos Flex og Jünger, som ligner hinanden derved, at de på forskellig vis lader en ideologisk komponent være retningsbestemmende for deres krigsrepræsentationer - i det ene tilfælde i en grad, så den krig, der skrives om, er tæt på helt at forsvinde bag en naturromantisk dannelsestradition (Flex), i det andet tilfælde på en langt mere subtil vis, for så vidt som den ubetvivlelige bestræbelse på at skildre krigen sagligt og nøgternt her går hånd $\mathrm{i}$ hånd med en fremadrettet ideologisk heroisme (Jünger).

Lad mig til sidst forsøge at anskueliggøre denne pointe ved at kaste et blik på den tredje af romanerne, Remarques Intet nyt fra Vestfronten, som adskiller sig fra de to andre ved sin insisteren på at være nutid og intet andet, ja, som i en vis forstand fortæller historien om, hvorfor det netop ikke længere er muligt at søge tilflugt $i$ mytologi eller ideologi, fortid eller fremtid. Også det har noget med forfatterens alder at gøre, til trods for at det som allerede antydet måske ikke forekommer indlysende, at de få år, der skiller Remarque og Jünger, skulle have nogen betydning for deres verdenssyn og krigserfaring. Et blik på romanens fortalte tid synes da heller ikke umiddelbart at bekræfte denne antagelse. Som hos Flex og Jünger hører vi også her om en generation af unge, der "med begejstring og god vilje" (Remarque 2011: 24) melder sig som krigsfrivillige i august 1914, om end deres forventninger hurtigt afløses af mismod og desillusion, da de under de ti ugers uddannelse, der går forud for frontindsatsen, lærer den sadistiske kadaverdisciplin at kende i skikkelse af korporal Himmelstoß, og altså slet ikke når at lide skibbrud i mødet med krigen. Men interessant nok er dette som sagt ikke Remarques egen historie, selv om romanen ofte læses som en maskeret selvbiografi. Til forskel fra Flex og Jünger meldte han sig ikke frivilligt, men blev derimod indkaldt som rekrut umiddelbart efter sin 18-års fødselsdag, i november 1916, indsat på Vestfronten i juni 1917 efter at have gennemgået et længere uddannelsesforløb, såret godt en måned senere i ben, arm og hals, hvorpå han tilbragte det næste år på et lazaret og først raskmeldtes til tjeneste ti dage inden våbenstilstanden.

Hvorfor er det nu interessant at vide, når der er tale om en roman? Det er det af den simple årsag, at det nok så meget er 
disse erfaringer, der projiceres tilbage på Paul Bäumer, romanens hovedperson og fortæller, og hans kammerater. Så paradoksalt det lyder, kan Remarque derfor med endog endnu større ret end Jünger hævde at være et ægte barn af krigen, at tilhøre den årgang, der havde krigen som sit eneste erfaringsgrundlag, og som derfor hverken har noget at falde tilbage på eller noget at se frem til. Det bliver i romanen for alvor klart, da Paul Bäumer under sin orlov genser hjem og familie og med sorg må konstatere, at der "ligger en kløft mellem i dag og dengang", at det ikke vil lykkes for ham "at finde tilbage" til sine bøger og kæreste minder, ja, at han "aldrig skulle være taget på orlov." (Remarque 2011: 120ff) Han er en fremmed og vil forblive det resten af sit liv, han forstår ikke det sprog, der tales i denne anden verden, eller som det hedder et andet sted $\mathrm{i}$ romanen, der foregriber orlovserfaringen: "I dag ville vi gå omkring i vores ungdoms landskab som rejsende. [...] Vi er forladte som børn og erfarne som gamle mennesker, vi er rå og triste og overfladiske - jeg tror, vi er fortabt." (Remarque 2011: 90) Og netop derfor, lyder romanens centrale påstand, er det heller ikke muligt at se fremad, at drømme om eller lægge planer for den tid, der måtte følge efter krigen. Paul Bäumer og hans jævnaldrende er bogstaveligt talt fanget i krigens ingenmandsland, der udgør deres eneste erfaringshorisont, de er kort sagt den fortabte generation:

Man vil heller ikke forstå os - for foran os vokser en generation, som ganske vist tilbragte årene her sammen med os, men som havde seng og arbejde og nu vender tilbage til deres gamle positioner, hvor de vil glemme krigen, - og bag os vokser en generation, ligesom os selv tidligere, den vil være fremmed for os og skubbe os til side. Vi er overflødige for os selv, vi vil vokse, nogle vi tilpasse sig, andre føje sig, og mange vil være rådvilde; - årene vil rinde bort, og til sidst vil vi gå til grunde. (Remarque 2011: 198)

$\mathrm{Nu}$ forekommer det muligvis ikke helt indlysende, hvordan fortælleren af denne og mange tilsvarende overvejelser i romanen skulle kunne vide det så sikkert, når han, som det fremgår umiddelbart efter den citerede passage, ikke selv overlever krigen. Det egentlig oprørende ved romanen ligger dog ikke i denne stadige anticipation af egen fremtidig fortabelse, men i et gennemgående træk ved nutidsbeskrivelsen, som man ikke desto mindre kan være tilbøjelig 
til at læse hen over. For Paul Bäumer og hans kammerater er godt nok fanget i krigens absolutte nutid, afskåret enhver forbindelse til fortid og fremtid. ${ }^{9}$ Forstået som umiddelbar livs- og oplevelsessammenhæng forekommer krigen imidlertid ikke alene overraskende uproblematisk, den er frem for alt kendetegnet ved en næsten ubrudt række af lykkelige, meningsfulde øjeblikke - fra latrinscenen ("Man kunne sidde sådan for evigt", 16) over rekvireringen, tilberedningen og fortæringen af gåsen og det amourøse eventyr med de franske piger til den 14 dage lange loppetjans, der går ud på at bevogte et proviantdepot med masser af mad, vin, kaffe og cognac ('Landsbyen forsvinder langsomt under granaterne, og vi forer et lykkeligt liv", 163). Mere end noget andet er det disse og tilsvarende episoder, der kommer til at bestemme krigens rum i Intet nyt fra Vestfronten - og så selvfølgelig én ting til, der forekommer så evident, at man kvier sig ved at nævne det: kammeratskabet og i særdeleshed venskabet med den noget ældre og mere erfarne Katczinsky eller Kat, som han hedder blandt venner.

Så langt Flex, Jünger og Remarque måtte ligge fra hinanden i såvel politisk orientering som vægtning af fortid, nutid og fremtid, er det $\mathrm{i}$ hvert fald én ting, der forbinder de tre fremstillinger - betoningen af kammeratskabets helt konkrete betydning i ekstremsituationer som disse. Alligevel er det vanskeligt at overse, at der selv på dette basale punkt synes at være en betydelig forskel på de tre bøger. Mens Flex og Remarque over lange stræk kan læses som en mere eller mindre højstemt og sentimental besyngelse af det tætte, inderlige, hos Flex næsten homoerotiske venskab, er der noget køligt over Jüngers beskrivelse af kammeratskabet, der intetsteds synes at række ud over våben- eller slagsbrødrenes fællesskab og derfor heller ikke afgiver samme 'staldvarme' som de to andre. Uanset den enorme mentalitets- og socialhistoriske afstand, der er mellem Flex og Remarque, tilbyder de således begge en mulighed for indlevelse, som ikke i tilsvarende grad findes hos Jünger eller i hvert fald her er forbeholdt en esoterisk kreds af ligesindede. For at vende tilbage til det spørgsmål, der blev stillet $i$ artiklens begyndelse, forekommer det på den baggrund nærliggende at antage, at denne forskel samtidig er en væsentlig del af forklaringen på, hvorfor Jünger ikke kom bare $\mathrm{i}$ nærheden af samme salgstal og popularitet som Flex og Remarque. Kun de færreste kunne i 1920erne nære noget ønske 
at læse om udsmeltningen af en ny, endnu mere martialsk og hård mennesketype, der allerede pegede frem mod den næste krig. Derimod følte mange utvivlsomt et stort behov for at bearbejde de foregående års traumatiske erfaringer af såvel individuel som kollektiv karakter, og det imødekom Flex og Remarque på hver sin måde ved at tilbyde en kompleksitetsreducerende fortælling om venskabets betydning, i Remarques tilfælde endda tilsat en generationelt bestemt forklaring på mistrivsel $\mathrm{i}$ årene efter krigen.

\section{Noter}

1 I den engelsksprogede litteratur taler man ligefrem om "War Boom" i perioden 1929-30. En oversigt over fænomenet findes i Eksteins 2000: $275 \mathrm{ff}$

2 Hans minde holdes dog stadig i hævd i mere sekteriske kredse. Efter 1970 har hans forfatterskab således været varetaget af det nationalistiske forlag Orion-Verlag (senere Orion-Heimreiter Verlag), der blev etableret i de første efterkrigsår af den uforbederlige sudetertyske nazist og forfatter Ernst Frank og efter dennes død er blevet videreført af højreekstremisten Dietmar Munier. Seneste oplag af Der Wanderer er fra 1997.

3 Som man har kunnet forvisse sig om siden udgivelsen af dagbøgerne i 2010 (jf. Jünger 2010).

4 Førsteudgaven udgav Jünger selv, bistået af sin far, der tog sig af boghandler- og pressekontakt. Oplaget var på 2000 eksemplarer, der blev solgt på godt et år. I 1922 udkom så andenudgaven på militærforlaget E. S. Mittler \& Sohn, i et førsteoplag på 5000 eksemplarer, og sådan fortsætter det frem til 1929. Hele publikationshistorien dokumenteres i Kiesels historisk-kritiske udgave (Jünger 2013: 445ff).

5 Det følgende afsnit parafraserer de relevante sider i mit kapitel om den wilhelminske periode, hvor man også vil kunne finde henvisninger til sekundærlitteratur (Paulsen 2012). Specifikt om Flex og ungdomsbevægelsen se også Ulbricht 1986.

6 Maleren og grafikeren Hugo Reinhold Karl Johann Höppener eller Fidus ('den trofaste'), som hans kunstnernavn lød, skabte flere af ungdoms- og livsreformbevægelsens ikonografiske billeder. Bedst kendt er utvivlsomt billedet af den nøgne mand, der tilbeder solen i Lichtgebet. Fidus arbejdede med motivet fra 1890erne til slutningen af 1930erne og nåede at udfærdige mindst elleve forskellige versioner i diverse materialer og formater (Paulsen 2012: 194f).

7 Ingen seriøs Jünger-eksegese kommer udenom at tage stilling til den sær- 
lige arbejdsform, som kendetegner værket og i særdeleshed I stålstormen. Jünger anså ikke sine tekster for færdige, men gennemskrev og reviderede dem med jævne mellemrum, ofte med betydelige ændringer til følge. I stålstormen findes således i ikke færre end syv til dels meget forskellige udgaver fra hhv. 1920, 1922, 1924, 1934, 1935, 1961 og 1978. Hvor intet andet er nævnt, citerer jeg her efter den seneste udgave, som også ligger til grund for den danske oversættelse. En kortfattet gennemgang og diskussion af de forskellige udgaver findes i mit efterskrift til den danske udgave (jf. Jünger 2012: 283ff). Uomgængelig for enhver fremtidig beskæftigelse med teksten er Kiesels tekstkritiske udgave, der ved hjælp af en farvekode overskueligt anfører samtlige ændringer i ét og samme tekstbillede (jf. Jünger 2013).

8 Den ofte karikerede pikkelhue, der siden 1843 havde fungeret som hovedbeklædning i den preussiske hærs infanteri, afløstes i 1916 af stålhjelmen, som ikke alene var mere funktionel og tidssvarende i sit look, men også var lettere og billigere at masseproducere - et meget håndfast udtryk for overgangen til den industrielle krig. Stålhjelmen opnåede hurtigt ikonografisk status og blev i 1920erne selve symbolet på frontsoldaten (jf. Hüppauf 1993).

9 Det følgende afsnit står i gæld til Müller 1986: $49 \mathrm{ff}$

\section{Litteratur}

Eksteins, Modris (2000): Rites of Spring. The Great War and the Birth of the Modern Age, London: Macmillan.

Flex, Walter (1917): Der Wanderer żwischen beiden Welten. Ein Erlebnis, München: C. H. Beck.

Hüppauf, Bernd (1993): "Schlachtenmythen und die Konstruktion des 'Neuen Menschen"” i Gerhard Hirschfeld m.fl. (red.): Keiner fühlt sich hier mehr als Mensch... Erlebnis und Wirkung des Ersten Weltkriegs, Essen: Klartext Verlag, s. 43-84.

Jünger, Ernst (2010): Kriegstagebuch 1914-1918, udg. af H. Kiesel, Stuttgart: Klett-Cotta.

Jünger, Ernst (2012): I stålstormen, overs. af A. Paulsen og H. Rundqvist, København: Gyldendal.

Jünger, Ernst (2013): In Stablgewittern. Historisch-kritische Ausgabe, 2 bd., udg. af H. Kiesel, Stuttgart: Klett-Cotta.

Koch, Lars (2005): Der Erste Weltkrieg als Medium der Gegenmoderne. Zu den Werken von Walter Flex und Ernst Jünger, Würzburg: Königshausen \& Neumann.

Koselleck, Reinhart (1988): "Erfahrungswandel und Methodenwechsel. Eine historisch-anthropologische Skizze" i Chr. Meier m.fl. (red.): Historische Methode, München: dtv, s. 13-61. 
Krumeich, Gerd (2001): "Langemarck" i Etienne François m.fl. (red.): Deutsche Erinnerungsorte, bd. 3, München: C.H. Beck, s. 292-309.

Medicus, Thomas (1999): "Jugend in Uniform" i Bernd Ulrich m.fl. (red.): Willensmenschen. Über deutsche Offiziere, Frankfurt a. M.: Fischer Verlag, s. 94-108.

Müller, Hans-Harald (1986): Der Krieg und die Schriftsteller. Der Kriegsroman der Weimarer Republik, Stuttgart: Metzler.

Paulsen, Adam (2012): "Den wilhelminske periode 1890-1918” i Anna Sandberg \& Detlef Siegfried (red.): Tysk kulturbistorie fra 1648 til i dag, København: Gyldendal, s. 180-217.

Remarque, Erich Maria (2011): Im Westen nichts Neues, Köln: Kiepenheuer \& Witsch.

Sautermeister, Gert (1985): "Vom Werther zum Wanderer zwischen beiden Welten. Über die metaphysische Obdachlosigkeit bürgerlicher Jugend" i Thomas Koebner m.fl. (red.): 'Mit uns zieht die neue Zeit": Der Mythos Jugend, Frankfurt a. M.: Suhrkamp, s. 438-78.

Ulbricht, Justus H. (1986): "Der Mythos vom Heldentod - Entstehung und Wirkung von Walter Flex' 'Der Wanderer zwischen beiden Welten"' i Jahrbuch des Archivs der deutschen Jugendbewegung, vol. 16, s. 111-56. 
